قسـم : التشريح والـهستولوجيا

كلية الطب البيطري - جامعة أسيوط•

رئيس القسم : أ •د•/ حلمي بدوي•

$$
\text { در'اسات جراحية تشريحية على الاكياس الزلالية للكتف في الحمار, }
$$

عبد الله حفني ، اسماعيل عبدالعزيز ، علي عبدالقادر ، ط•ب • محمد طه

أجرى هذاللبحث على عدد واحد جنين وآخر مولود حديثا وثلاثة حيوانات صغيرة ومr

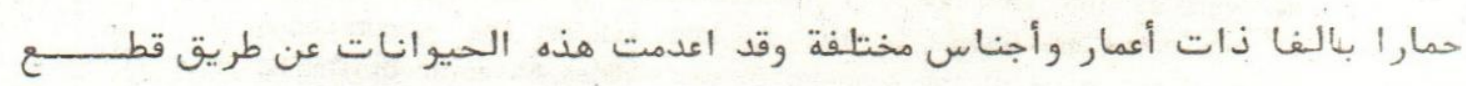

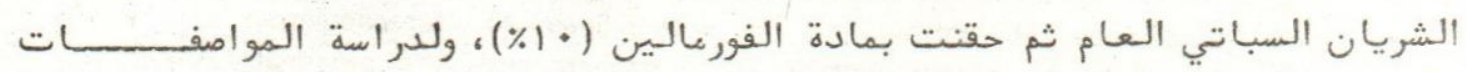

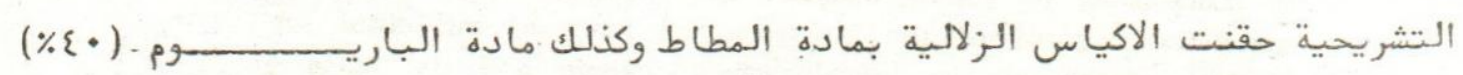
والبيوروجر افين.

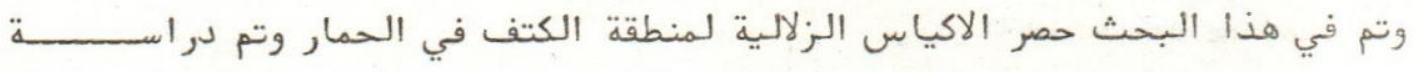
الوصف التشريحي لهه وذلك بتحديد موقعها وشكلها وعلاقتها بالتر اكيب المجاورة وتقديـر حجمها وتحديد أنسب مكان لحقنها جراحيا ومقارنتها ومثيلاتها في الحيوانات المختافـــة وقد وجد أن الاكياس الزلالية للكتف في الحمار هي:

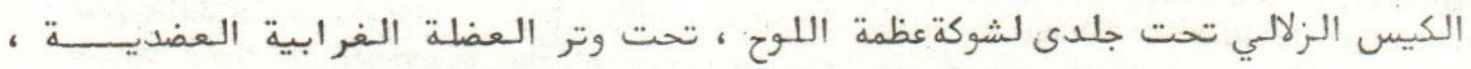

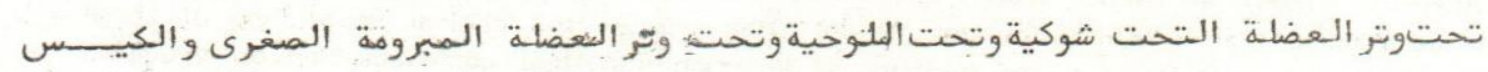

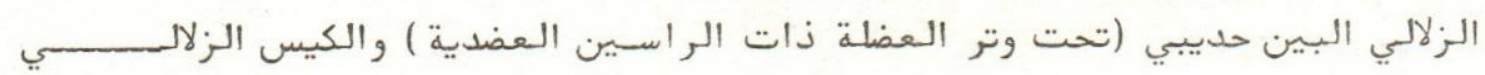

الداني والقاصي تحت وتر العضلة العضدية الدماغية وكيس زلالي العضلة تحت ترقوية • 
Dept. of Anatomy \& Histology,

Faculty of Vet. Med., Assiut University,

Head of Dept. Prof. Dr. H. Badawi.

\title{
SURGICAL ANATOMICAL STUDIES ON THE SYNOVIAL BURSAE OF THE SHOULDER IN DONKEY \\ (Equus asinus) \\ (With 4 Figures)
}

\author{
By \\ A. HIFNY; I.A. IBRAHIM; A.A. MANSOUR and M. TAHA \\ (Received at 25/7/1987)
}

\section{SUMMARY}

This work was carried out on one fetus, one newlyborn, 3 young and 35 adult donkeys of different sexes and ages. The morphology of the bursae was studied as regard to the shape, position, relation as well as the frequency of its occurance and the suitable site of injection. The bursae of the shoulder include; the subcutaneous bursa of the spine of the scapula, B. subtendinea M. coracobrachialis, B. subtendinea $M$. infraspinati, B. subtendinea $M$. subscapularis, B. subtendinea $M$. teretis minoris, B. intertubercularis, the proximal subtendinous bursa of the brachiocephalic muscle, the distal subtendinous bursa of the brachiocephalic muscle and the bursa of the M. subclavius. From the clinical point of view there is no communication between these bursae and the adjacent joint capsule of the shoulder joint.

\section{INTRODUCTION}

The study of the synovial bursae forms an important link between the anatomy and surgery. However, available literatures lack many informations about the surgical anatomical characters of the bursae in donkey. MULLER (1936), OTTAWAY/WORDEN (1940), BERG (1973), and SEIFERLE/FREWEIN (1986) in horse, M'CLEOD (1958), GIGOV (1964) and RAGHAVAN/ KACHROO (1964) in cattle, stated only the frequency of the occurance of these bursae in the studied animal. Therefore the present study discuss the clinical importance of these bursae, site of their location and methods of injection and their communication or loculation with the joint capsule.

\section{MATERIAL and METHODS}

This work was carried out on one fulterm fetus with C.V.R.L. $78 \mathrm{~cm}$, one newly born, 3 young and 35 donkeys of different ages and sexes. These materials were subjected to different methods of techniques for studying the bursae, by injection of Gum milk (latex) and Radioopaque materials after bleeding the animal through the common carotid artery, then injected with $10 \%$ formalin. The morphology of the bursae was studied as regard to the shape, position, relation as well as the frequency of its occurance and the suitable site of injection. The nomenclature-used in this work is that adopted by N.A.V. (1983) whenever if it was possible. 


\title{
A. HiFNY et al.
}

\begin{abstract}
RESULTS
Subcutaneous bursa of the spine of the scapula :

This bursa was observed only in 4 of the examined cases. It is subfascially situated above the proximal end of the spine of the scapula just proximal to the tuber spinae. Its long axis is parallel to the long axis of the spine of the scapula. Its cavity is intersected by connective tissue fibers which give it a multilocular appearance. When the bursa is injected with latex and hardened in situ, the latex cast appears oval in outline, wide proximally and narrow distally. It measures about $3.1 \mathrm{~cm}$ proximodistally and $2 \mathrm{~cm}$ transversly.
\end{abstract}

B. subtendinea $M$. coracobrachialis :

This bursa was observed in all of the examined specimens. It is relatively large and lies $1.3 \mathrm{~cm}$ distal to the coracoid process on the medial aspect of the shoulder joint between the tendon of origin of the $M$. coracobrachialis, as well as its adjacent fleshy part medially and the tendon of insertion of the $M$. subscapularis laterally $(1 / 1,2)$. The wall of this bursa is firmly attached to the tendon of origin of the $M_{\text {. }}$ coracobrachialis and easily detached from the tendon of insertion of the M. subscapularis. When the bursa is injected with latex and hardened in situ, its latex cast appears quadrilateral in outline, measures about $3.7 \mathrm{~cm}$ proximodistally and $1.7 \mathrm{~cm}$ craniocaudally in adult donkeys while in newly born donkey it measures about $3 \times 1.5 \mathrm{~cm}$.

\section{B. subtendinea $M_{0}$ infraspinati :}

This bursa was observed in all of the examined specimens. It is situated between the long tendon of insertion of the $M$. infraspinatus and the lateral surface of the caudal part of the greater tubercle of humerus as well as the adjacent area on its lateral surface.

When the bursa is injected with latex and hardened in situ, the cast appears quadrilateral in outline with its long axis directs obliquely, distally and cranially $(1 / 3,2 / 4 \quad A, B, C)$. It measures about $2.8 \mathrm{~cm}$ length and $1.9 \mathrm{~cm}$ width. It was observed that there is no connection between the bursa and the articular capsule of the shoulder joint.

This bursa projects crannially beyond the long tendon of isertion of the M. infraspinatus and projects caudally to come incontact with the $M_{0}$. teres minor. The cranially projected part is considered the suitable site for injection of this bursa.

\section{B. subtendinea Mo subscapularis :}

In the present work this bursa is observed in 14 cases. It is small and irregularly semicircular in outline. It lies between the tendon of insertion of M. subscapularis without reaching its cranial or caudal borders and the medial wall of the joint capsule of the shoulder joint on the lesser tubercle of the humerus. Its wall is intimately attached to the tendon of insertion of M. subscapularis medially and the articular capsule of the shoulder joint laterally.

\section{B. subtendinea $\mathrm{M}$. teretis minoris :}

This bursa was not observed in fetus, newly born and young donkeys and recorded in 12 of the adult examined specimens. It is situated between the $M$. teres minor and the articular capsule of the shoulder joint above the craniolateral part of the head of the humerus. The bursa is small and semicircular in outline (about $1 \times 1 \mathrm{~cm}$ ).

Assiut Vet.Med.J.Vol. 20, No. 39, 1988. 


\section{THE SYNOVIAL BURSES OF THE SHOULDER}

\section{B. intertubercularis :}

The intertubercular bursa is the largest one of these of the bursae of the shoulder of donkey and is recorded in all dissected specimens. It is situated between the tendon of

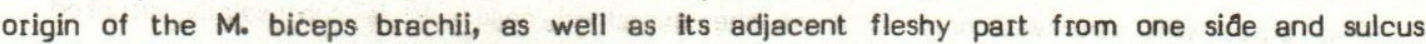
intertubercularis, as well as the adjacent part of the cranial surface of the humerus on the other side $(2 / 1,2,3 ; 1 / 4)$. It is separated from the articular capsule of the shoulder joint by a pad of fat.

The permenant occurance of this bursa may be due to the fibrocartilaginous tendon of origin of the M. biceps brachii and its gliding on sulcus intertubercularis at the angle of the shoulder.

The wall of the bursa intertubercularis is firmly attached to the tendon of origin of the M. biceps brachii and the sulcus intertubercularis. Its area of attachment to the humerus is smaller than that to the $M$. biceps brachii.

When the bursa intertubercularis is injected with latex and hardened in situ, its cast appears quadrilateral in outline, measures about $5.3 \times 5.4 \mathrm{~cm}$ proximodistally and mediolaterally in adult donkeys and $4 \times 4.1 \mathrm{~cm}$ in newly born one.

The shape of the deep surface of the latex cast differs according to the type of movement of the shoulder joint. In normal standing position ( $4 \mathrm{~A} / 1$ ) the middle third of the deep surface of the cast moulds the intertubercular sulcus while the other two thirds are smooth. In case of flexion $(4 \mathrm{~B} / 1)$ the bursa extends proximal to the limit of the sulcus intertubercularis, therefore the distal third of the surface moulds the intertubercular sulcus while the remaining part of this surface is smooth. On the other hand, in case of extension $(4 \mathrm{C} / 1$ ) the bursa extends distally beyond the sulcus intertubercularis. Therefore, the proximal thrid of the deep surface moulds the sulcus intertubercularis while the distal two thirds are smooth.

In the present work the suitable site of injection of this bursa is between the borders of the tendon of origin of the M. biceps brachii and the cranial parts of the greater or lesser tubercles of the humerus as in these parts the bursa reflects around the tendon of M. biceps brachii.

The proximal subtendinous butsa of the brachiocephalic muscle :

This bursa is recorded in both limbs in 6 cases and in one limb in two cases of the examined adult donkeys. It is situated between $\mathrm{M}_{0}$ brachiocephalicus and the tendon of insertion of M. infraspinatus above the caudal part of the greater tubercle of the humerus. The latex cast of this bursa takes a variable shape and size, it varies from semicircular to irregular quadrilateral in outline and its measurements ranges from $(2 \times 1.5 \mathrm{~cm})$ to $(2 \times 3 \mathrm{~cm})$. It has a deep surface which is concave and smooth adapted to the bone, and a superficial surface which is convex and related to M. brachiocephalicus.

\section{The distal subtendinous bursa of the brachiocephalic muscle :}

This bursa is recorded in both limbs in 4 cases and in one limb in 3 cases of the examined adult donkeys. It is situated above the cranial part of the greater tubercle of the humerus. This bursa is semicircular in outline, its wall is attached to the cranial part of the greater tubercle of the humerus and is separated by a tendinous sheet from the laterally evaginated part of the bursa intertubercularis.

Assiut Vet.Med.J.Vol. 20, No. 39, 1988. 


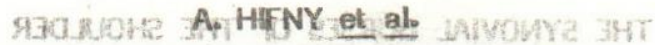

The bursa of the M. subclavius :

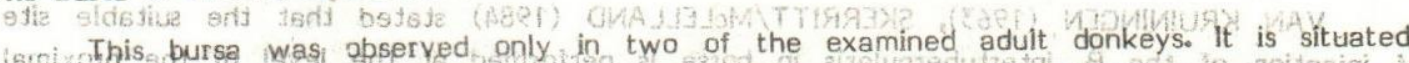

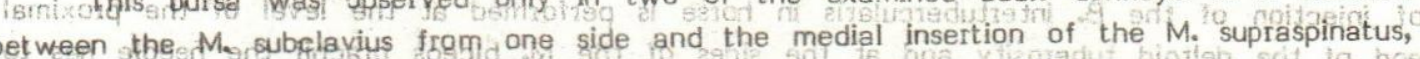
ther mediati part of the tendizous sheet oovers the medially reflected part of the $B$. intertupercularis, as well as the cranial part of the lesser tubercle of the humerus on the other sidevisthe pursa is relatively large, semicipcular in outline, and measures $2.8 \mathrm{~cm}$ in diameter. Its wall is logsely attached to the M. subclavius and is firmly attached to the other related structures.

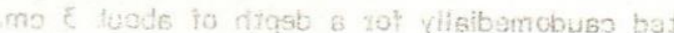

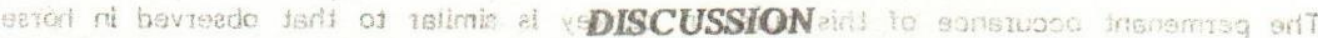

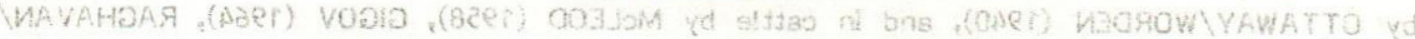
nobns The subdarteous bursabof the spine of the scapula was notracorded (in N N.A.Ve (1983). however, OfTAWAY7WORDEA observed a subcutanedus bursa on the tuber spinae but they did nat mentioned it seraninglogb:

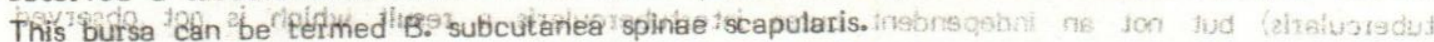

The situation of the B. subtendinea M. curacobrachialis in donkey is similar (

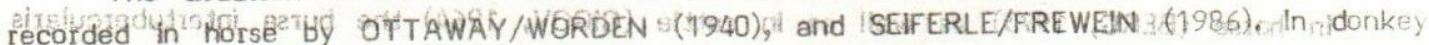

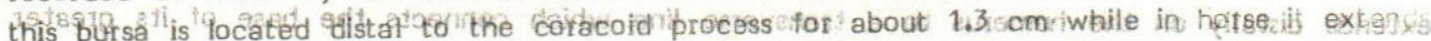

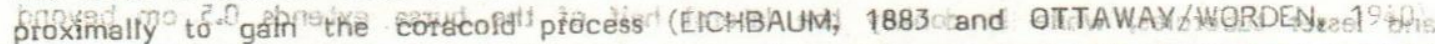

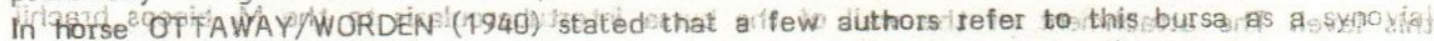

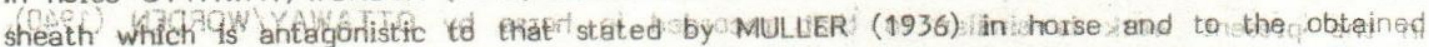

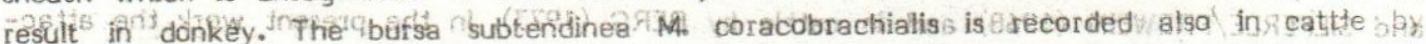

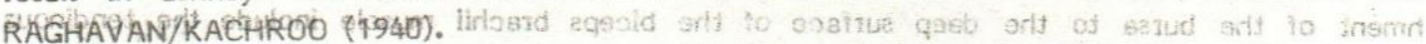

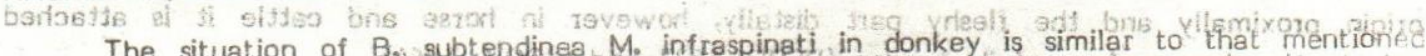

The situation of Busphtendinga $M_{0}$ infraspinati in donkey is similar to that mentionec
(1940), SISSON (1975) and SEIFERLE/FREWEIN (1986) in hopse, as by, OTTAWAY/WORDEN (1940), SISSON (1975) and SEIFERLE/FREWEIN (1986) in holse, as WetP as McLEOD (9958), GIGOVJa(1964) and RAGHAVAN/KACHROOIe(1964) ain Cattle. In this

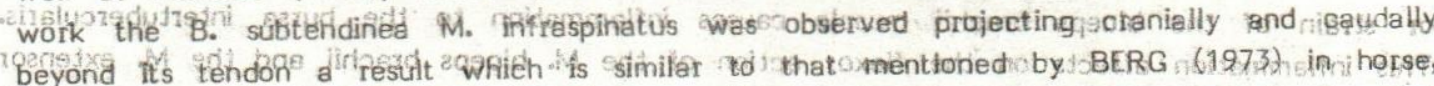
while in contfast $t 0^{i}$ this result SEIFERLE/FREWEIN (1986) recorded that this bursa is ilpzot fujded rom the cranial marbin of the M. infraspinatus and considered it a suitable site fonsinjection of this bursa. Thisegite is also the acurate one for injecting this bursa in our work. fla was

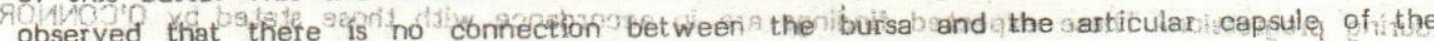
shoulder joint in donkey an result which is in agreeinent with that reported byM BERG (1973)

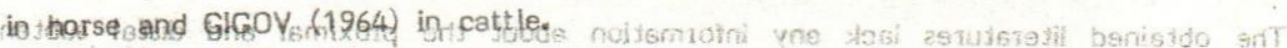

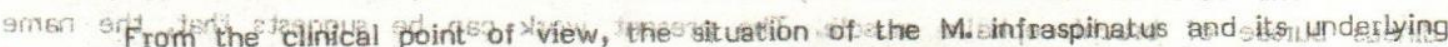

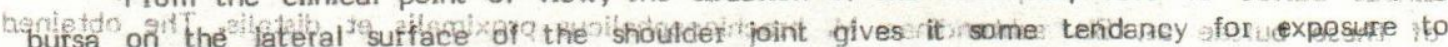
trauma. Moreover, stlaing of slippety vor falling downolof (che animah may lexpose the tendon for sprain or strain of the bursaevifor unflammation. Whe preceding causes are similas to those stated in case of bursitis of the bursa subtendinea $M_{0}$. infraspinatus in horse by BONE, CATCOTT/GABEL/JOHNSON/RILEY (1963) The signs that reflected on the animal is abduction of the entire limb. These signs are in agreement with that reported by SKERRITT/McLELLAND (1984), the foot is placed outwards to relieve tension on the inflammed tendon. bra eies The B. subtendinea Mo teret is minoris was recorded in thorse byMOTTAWAYLWORGAT (1940) and SISSON" (1975). "The first auther mentioned that this bursa may communicate with the cavity of the shoulder joint while the second author mentioned. its possibility to rondomunicate with the bursa subtendinea Molinfraspinati, an result which was onot observed

in the present work. anel paliogly

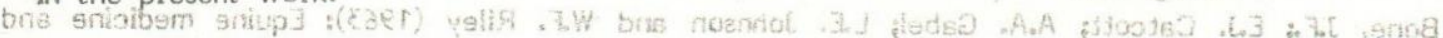

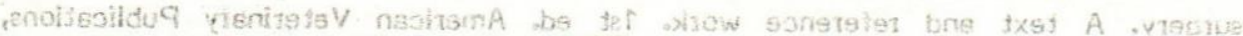

Assiut Vet-Meda.Vol. 20, No. 39, 1988. 


\section{THE SYNOVIAL BURSES OF THE SHOÚLDER}

VAN KRUININGEN (1963), SKERRITT/MCLELLAND (1984) stated that the suitable site of injection of the B. intertubercularis in horse is performed at the level of the proximal end of the deltoid tuberosity and at the sides of the M. biceps brachii the needle has to be directed proximally along the bone. ATTIA/OTHMAN (1986) in donkey mentioned that the bicipital bursa (inertubercular bursa) can be injected $2 \mathrm{~cm}$ just below the cranial part of the greater tubercle of the humerus and about $0.5: 1 \mathrm{~cm}$ caudally, the needle was inserted between $\mathrm{M}$. biceps brachii and the lateral border of the humerus. The needle was then directed caudomedially for a depth of about $3 \mathrm{~cm}$.

The permenant occurance of this bursa in donkey is similar to that observed in horse by OTTAWAY/WORDEN (1940), and in cattle by MCLEOD (1958), GIGOV (1964), RAGHAVAN/ KACHROO (1964) and BERG (1973) while the latter author added that, in pig the tendon of origin of the M. biceps brachii is invaginated in the capsule of the shoulder joint and so the articular capsule forms a synovial sheath around the tendon (Vagina synovialis intertubercularis) but not an independent bursa intertubercularis a result which is not observed in donkey.

In horse (BERG, 1973) as well as in cattle (GIGOV, 1964) the bursa intertubercularis extends distally on the humerus to a transverse line which connects the base of its greater and lesser tubercles, while in donkey the lateral half of the bursa extends $0.5 \mathrm{~cm}$ beyond this level. The attachment of the wall of the bursa intertubercularis to the M. biceps brachii in the present work is similar to that recorded in horse by OTTAWAY/WORDEN (1940), and SIEFERLE/FREWEIN (1968) and in cattle by BERG (1973). In the present work the attachment of the bursa to the deep surface of the biceps brachii muscle include the tendinous origin proximally and the fleshy part distally, however in horse and cattle it is attached only to the deep surface of its tendon (BERG, 1973 and GIGOV, 1964).

From the clinical point of view any severe traumatism to the point of the shoulder or strain of the biceps brachii muscle causes inflammation to the bursa intertubercularis. This inflammation affects on the flexor action of the $M_{0}$. biceps brachii and the $M_{0}$ extensor carpi radialis on the elbow joint, therefore the expected signs of the intertubercular bursitis is shortening of the strid due to restricted use of biceps and the animal can not make any attempt to lift the foot off the ground and usually the toe being dragged along the ground during progression. These expected findings are in accordance with those stated by O'CONNOR (1958), ADAMS (1962), BONE et al. (1963) and SKERRITT/M̈CLELLAND (1984).

The obtained literatures lack any information about the proximal and distal subtendinous bursae of brachiocephalic muscle. The present work can be suggests that, the name of these bursae as, Bb. subtendinae $\mathrm{M}_{0}$ brachiocephalicus proximalis et distalis. The obtained literatures as well as N.A.V. (1983) does not give any information about this bursa therefore the suggested name of the spresent work is B. M. subclavius.

\section{REFERENCES}

Adams, O.R. (1962): Lameness in Horses. Lea and Febiger, Philadelphia.

Attia, M. and G.M. Othman (1986): Pilot studies on the techniques for arthrocentesis and intraarticular and intrabursal injections in konkeys. Ass. Vet. Med. J. Vol. 17, No. 34.

Berg, R. (1973): Angewandte und Topographische Anatomie der Haustiere. Veb. Gustav Fischer Verlag Jena.

Bone, J.F.; E.J. Catcott; A.A. Gabel; L.E. Johnson and W.F. Riley (1963): Equine medicine and surgery. A text and reference work. 1st ed. American Veterinary Publications, I.N.C. 


\section{A. HIFNY et al.}

Eichbaum, F. (1883): Zur Anatomie und Histologie der Schleimbeutel und Sehnenscheides des Pferdes. Archiv F. Wissensch. U. Prakt. Thierheilk. Jg./Bd. 9.

Gigov, Z. (1964): Uber den Bau, die Blutversorgung und die Innervation der Gelenkkapseln der Extremitation beim Rind. Anat. Anz. Bd. 114.

M'Cleod, W.M. (1958): Bovine Anatomy. 2nd edition. Burgess publishing company; Manneapolis, Minnesota.

Muller, F. (1936): Schleimbeutel und sehnenscheiden des pferds. Arch. Miss. Parkt. Tierheilk. No. 70, Cited by OTTAWAY, 'C.W. and A.N. WORDEN (1940).

Nickel, R.; A. Schummer; K.H. Wille and H. Wilkens (1986): Passive locomotor system in NICKEL, R.; A. Schummer; E. Seiferle, J. Frewein, H. Wilkens and K.H. Wille (The Locomotr system of the Domestic Mammals). Verlag Paul parey. Berlin. Hamburg.

Nomina Anatomica Veterinaria (1983): Third edition. Published by the International committe on Veterinary Gross Anatomical Nomenclature under the financial responsibility of the world Association of Veterinary Anatomists. Ithaca, New York.

O'Connor, J.J. (1958): Dollar's Veterinary Surgery 4th edition. Bailliere. Tindall and Cox. London.

Ottaway, C.W. and A.N. Worden (1940): Bursae and tendon sheaths of the horse. Vet. recard Vol., 52, No. 26.

Raghavan, D. and Kachroo (1964): Anatomy of the ox. First edition. Indian council of agricultural research, New Delhi.

Seiferle, E. and J. Frewein (1986): Active locomotor system in Nickel, R.; A. Schummer; E. Seiferle, J. Frewein; H. Wilkens and K.H. Wille, the bcomotor system of the Domestic Mammals.

Sisson, S. (1975): Equine dMyology in SISSON and GROSSMAN'S, The Anatomy of The Domestic fAnimals, 5th ed. W.B. SAUNDERS COMPANY. Philadelphia-London-Toronto.

Skerritt, G.C. and. McLelland (1984): An Introduction to the functional Anatomy of the limbs of the Domestic Animals. Wright. Bristol.

Van Kruiningen, H.J. (1963): Practical techniques for making injections into joints and bursae of the horse. J.A.V.M.A. Vol. 143, No. 10. 


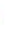




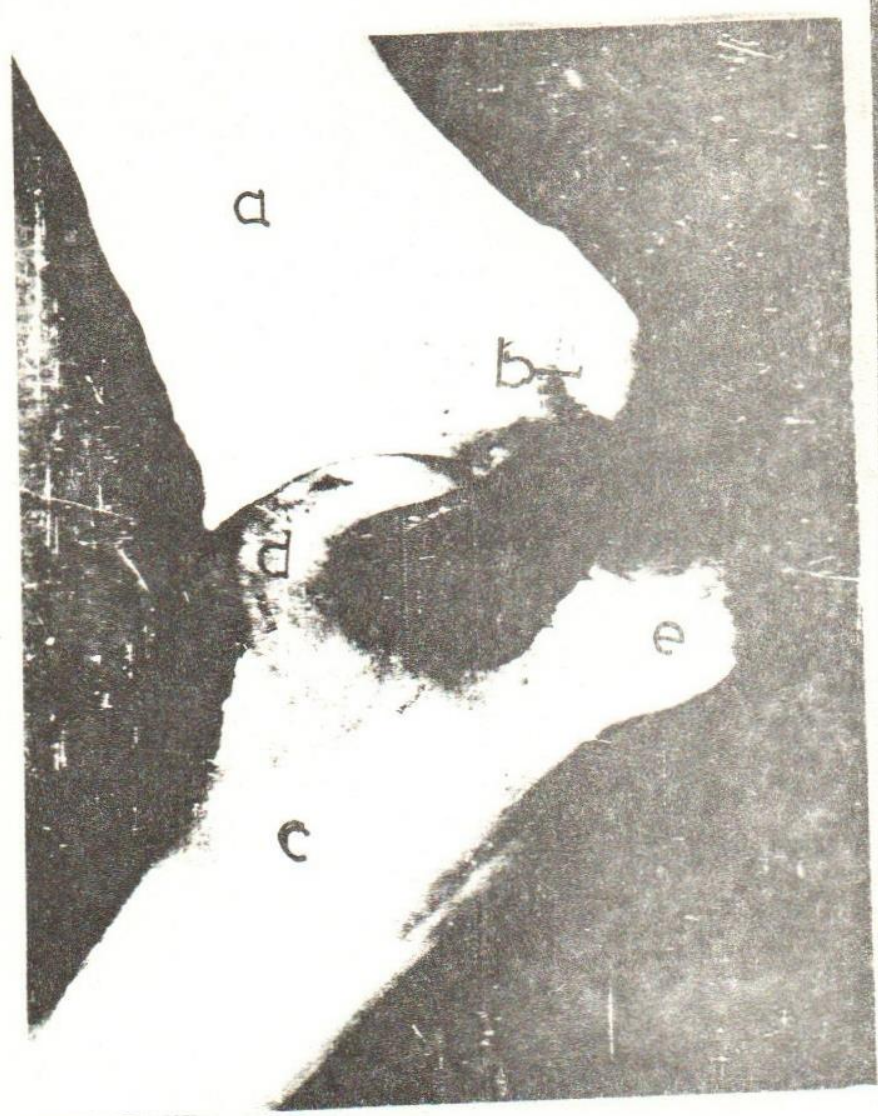

Fig. (1): Latex casts of the bursae of the left shoulder (Medial vievs).

1- B.subtendinea Mocoracobrachialis.

a- Scapula. b- Coracoid process

e- Cranial part of lesser tubercle of the humerus.

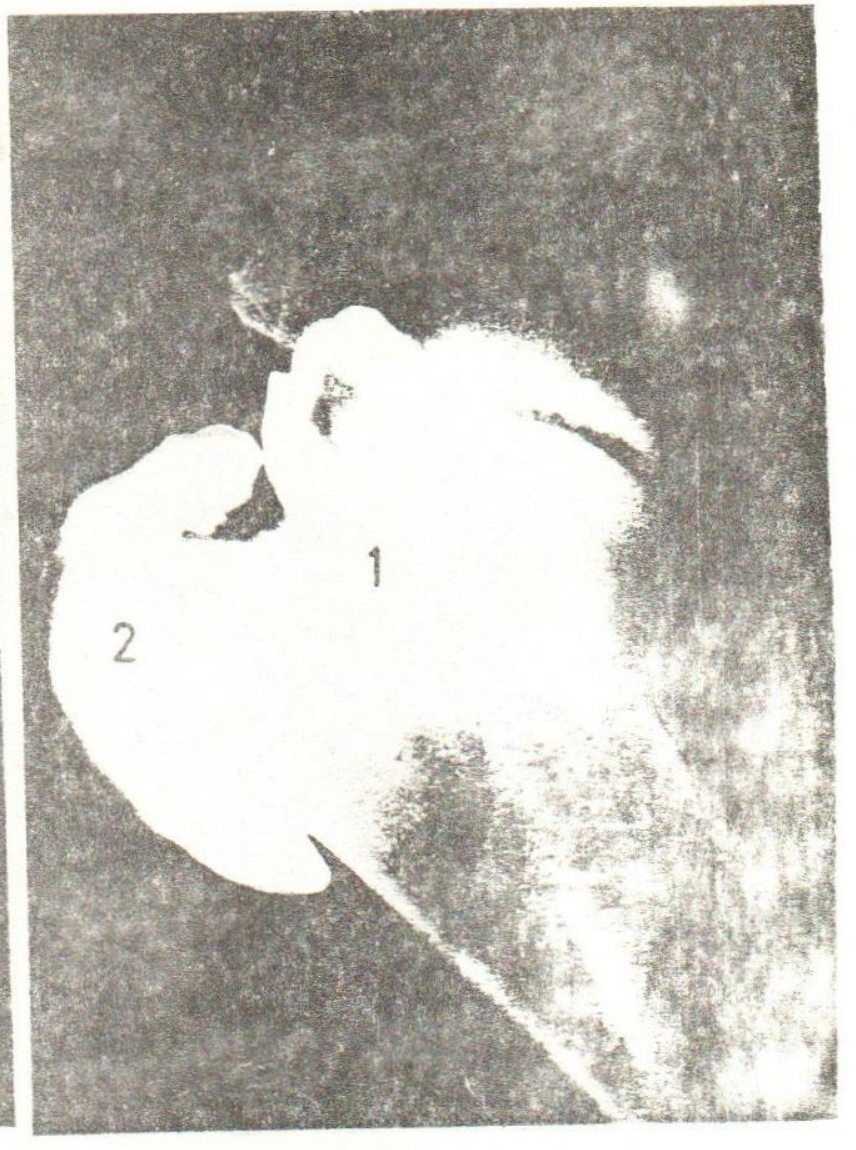

Fig. (2): Mediolateral radiograph showing the bursae of the right soulder. 2- Bointertubercularis.

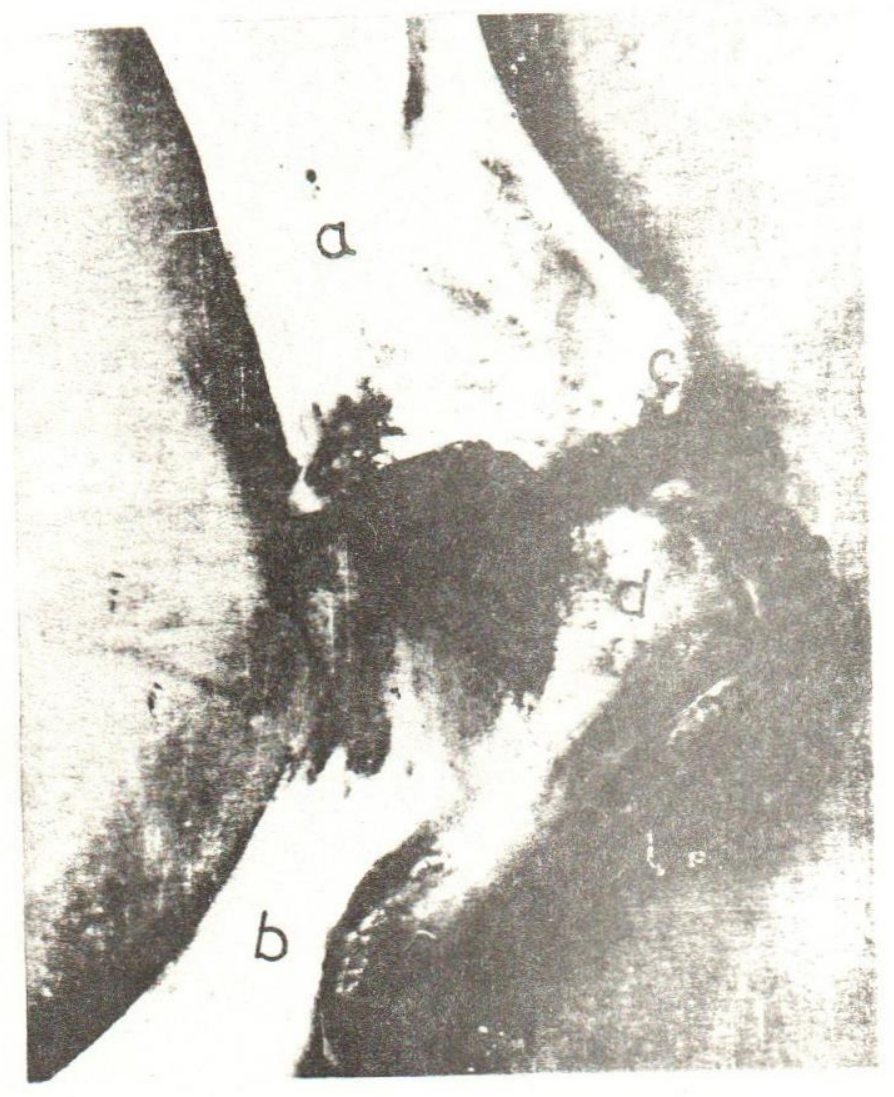

Fig. (3): Latex casts of the bursae of the right shoulder (lateral viev): 1- Besubtendinea $M_{0}$ infraspinati. 2- B. intrtubercularise
a. Scapula.
b. Humerus.
c. Supraglenaid tubercle.
d. Cranial part of greater tubercle of the humerc. 


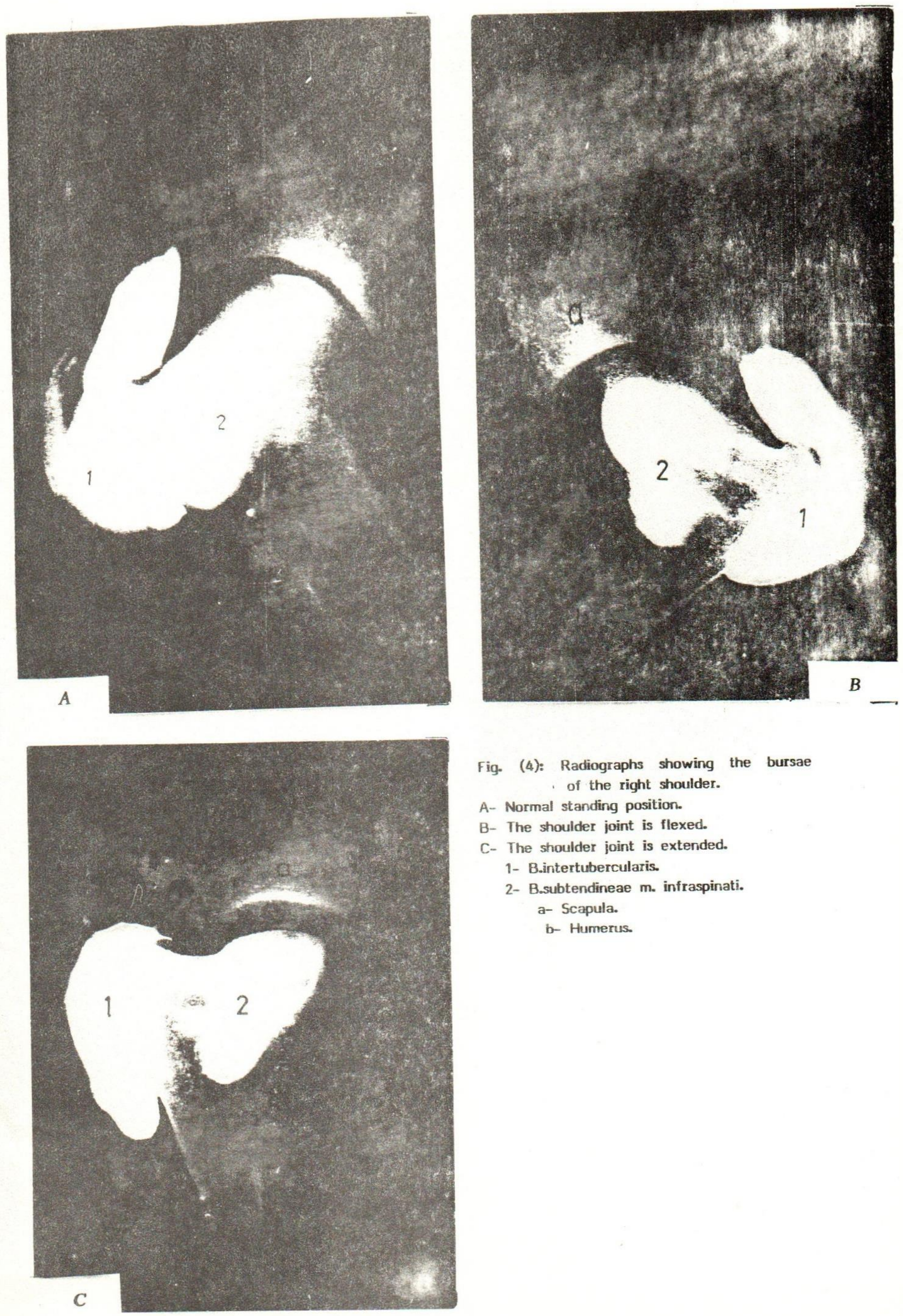

Fig. (4): Radiographs showing the bursae of the right shoulder.

A- Normal standing position.

B- The shoulder joint is flexed.

C- The shoulder joint is extended.

1- B.intertubercularis.

2- Bsubtendineae $\mathrm{m}$. infraspinati.

a- Scapula.

b- Humerus. 
